\title{
Diagnostic Yields and Clinical Impacts of Capsule Endoscopy
}

\author{
Seung Min Hong ${ }^{1,2,+} \mathbb{\infty}$, Sung Hoon Jung ${ }^{3,+}+\mathbb{C}$ and Dong Hoon Baek $1,2, * \mathbb{C}$ \\ 1 Department of Internal Medicine, Pusan National University School of Medicine, Busan 49421, Korea; \\ lucky77i@naver.com \\ 2 Biomedical Research Institute, Pusan National University Hospital, Busan 49421, Korea \\ 3 Department of Internal Medicine, Eunpyeong St. Mary's Hospital, College of Medicine, \\ The Catholic University of Korea, Seoul 03312, Korea; shjung74@catholic.ac.kr \\ * Correspondence: dhbeak77@gmail.com; Tel./Fax: +82-51-2448180 \\ + These authors contributed equally to this work.
}

check for

updates

Citation: Hong, S.M.; Jung, S.H.;

Baek, D.H. Diagnostic Yields and

Clinical Impacts of Capsule

Endoscopy. Diagnostics 2021, 11, 1842.

https://doi.org/10.3390/

diagnostics 11101842

Academic Editor: Yunjeong Lim

Received: 24 August 2021

Accepted: 29 September 2021

Published: 5 October 2021

Publisher's Note: MDPI stays neutral with regard to jurisdictional claims in published maps and institutional affiliations.

\begin{abstract}
Observing the entire small bowel is difficult due to the presence of complex loops and a long length. Capsule endoscopy (CE) provides a noninvasive and patient-friendly method for visualizing the small bowel and colon. Small bowel capsule endoscopy (SBCE) has a critical role in the diagnosis of small bowel disorders through the direct observation of the entire small bowel mucosa and is becoming the primary diagnostic tool for small bowel diseases. Recently, colon capsule endoscopy (CCE) was also considered safe and feasible for obtaining sufficient colonic images in patients with incomplete colonoscopy, in the absence of bowel obstruction. This review article assesses the current status of $C E$ in terms of the diagnostic yield and the clinical impact of SBCE in patients with obscure gastrointestinal bleeding, who have known or suspected Crohn's disease, small bowel tumor and inherited polyposis syndrome, celiac disease, and those who have undergone CCE.
\end{abstract}

Keywords: capsule endoscopy; diagnostic yields; clinical impact

\section{Introduction}

It is difficult to directly examine the small bowel because of its length (average length, $575 \mathrm{~cm}$ at the age of 20), and it is hard to use conventional endoscopic devices owing to the complex loops and length of the small bowel [1,2]. Conventional endoscopic devices can be used to observe only a small part of the proximal jejunum and distal ileum. Therefore, previously, small bowel radiography (SBR, small bowel follow-through (SBFT) and enteroclysis), push-enteroscopy, and small bowel angiography were used to examine the small bowel. The range of the small bowel that could be observed by push-enteroscopy was limited, despite considerable patient discomfort [3]. Therefore, the diagnostic yields of these imaging modalities were very low (push-enteroscopy, 35\%, SBR, 37\%) $[4,5]$.

Small bowel capsule endoscopy (SBCE) provides a noninvasive and patient-friendly method for visualizing the small bowel. SBCE was developed by Gavriel Iddan in the mid-1990s and was introduced in 2000 [6]. Subsequently, double balloon enteroscopy (DBE) was launched in 2001 [7], and SBCE and DBE notably enhanced the diagnosis and treatment of small bowel diseases. With the ability to directly observe the small bowel using SBCE, the diagnostic yield for small bowel diseases and clinical physicians' interest in treating small bowel diseases increased. Initially, after the development of SBCE, its diagnostic yield was higher than that of DBE. However, with more experience with DBE, there is almost no difference in the diagnostic yield in the two tests $[8,9]$. The reported pooled diagnostic yields for SBCE and DBE were $60 \%$ and $57 \%$, respectively [9]. Although with SBCE, biopsy or therapeutic intervention is impossible and it is difficult to determine the exact location of the lesion, SBCE is the first choice for evaluation of small bowel diseases, owing to its convenience and safety [9].

The main indications for SBCE are obscure gastrointestinal bleeding (OGIB) and Crohn's disease (CD). SBCE is also indicated for small bowel tumors and inherited poly- 
posis syndromes, celiac disease, chronic diarrhea, and chronic abdominal pain, and for clarifying abnormal small intestinal findings from other imaging examinations. In previous research, OGIB accounted for $66 \%$ of all SBCE indications, and the remaining SBCE indications were distributed between chronic abdominal symptoms $(10.6 \%), \mathrm{CD}(10.4 \%)$, small bowel tumor $(3.5 \%)$, and celiac disease $(1.7 \%)[10,11]$. Colon capsule endoscopy (CCE) has a high success rate (68 to $98 \%$ ) in patients who underwent incomplete colonoscopy due to the severe pain, severe mesenteric redundancy, and postoperative adhesions [12-16]. Additionally, CCE can reduce the risk of colonoscopy complications such as perforation.

Since the introduction of capsule endoscopy (CE) in clinical practice in 2001, CE has been improved to include a wider field-of-view, high-resolution imaging, longer battery life, and miniaturization; thus, the clinical application of $C E$ is gradually expanding. We evaluated the current status of $C E$ in terms of its diagnostic yield and the clinical impact of SBCE on patients with gastrointestinal bleeding, who have known or suspected CD, small bowel tumor and inherited polyposis syndrome, celiac disease, and those who have undergone CCE.

\section{Current Status of Small Bowel Capsule Endoscopy}

Since Given's first commercialization of SBCE in 2001, capsule endoscope systems currently in use include PillCam SB3 ${ }^{\circledR}$ (Medtronic, Dublin, Ireland), MiroCam ${ }^{\circledR}$ (Intromedic, Seoul, Korea), CapsoCam ${ }^{\circledR}$ (Capso-Vision, Saratoga, NY, USA), EndoCapsule ${ }^{\circledR}$ (Olympus, Tokyo, Japan), and OMOM Capsule ${ }^{\circledR}$ (Jinshan science and technology, Chongqing, China) (Table 1).

Table 1. Specifications of the currently available capsule endoscopy systems.

\begin{tabular}{|c|c|c|c|c|c|c|c|c|}
\hline $\begin{array}{l}\text { Capsule } \\
\text { Endoscopy }\end{array}$ & $\begin{array}{l}\text { Manufacturer } \\
\text { (Country) }\end{array}$ & $\begin{array}{c}\text { Dimensions } \\
(\mathrm{mm})\end{array}$ & $\begin{array}{l}\text { Imaging } \\
\text { Heads }\end{array}$ & $\begin{array}{c}\text { Field } \\
\text { of View }\left({ }^{\circ}\right)\end{array}$ & $\begin{array}{l}\text { Battery } \\
\text { Life (h) }\end{array}$ & $\begin{array}{c}\text { Frame Rate } \\
\text { (fps) }\end{array}$ & Communication & $\begin{array}{c}\text { FDA } \\
\text { Approval }\end{array}$ \\
\hline PillCam SB3 $^{\circledR}$ & $\begin{array}{l}\text { Medtronic } \\
\text { (USA) }\end{array}$ & $11.4 \times 26.4$ & 1 & 156 & $\geq 11$ & $2-6$ & RF & Yes \\
\hline MiroCam $\mathbf{4 0 0 0}^{\circledR}$ & $\begin{array}{l}\text { IntroMedic } \\
\text { (South Korea) }\end{array}$ & $10.8 \times 24.5$ & 2 (at one end) & 170 & 10 & $2 \times 2$ & EEP & Yes \\
\hline CapsoCam SV-1 ${ }^{\circledR}$ & $\begin{array}{l}\text { CapsoVision } \\
\text { (USA) }\end{array}$ & $11 \times 31$ & 4 & 360 & 15 & $12-20$ & $\begin{array}{l}\text { no communication } \\
\text { (stored in capsule) }\end{array}$ & Yes \\
\hline Endocapsule $10^{\circledR}$ & $\begin{array}{c}\text { Olympus } \\
\text { (Japan) }\end{array}$ & $11 \times 26$ & 1 & 160 & 12 & 2 & $\mathrm{RF}$ & Yes \\
\hline OMOM Capsule2 $^{\circledR}$ & $\begin{array}{l}\text { Jinshan Science } \\
\text { and Technology } \\
\text { (China) }\end{array}$ & $11 \times 25.4$ & 1 & 165 & 10 & 2 & $\mathrm{RF}$ & No \\
\hline PillCam Colon2 ${ }^{\circledR}$ & $\begin{array}{l}\text { Medtronic } \\
\text { (USA) }\end{array}$ & $11.6 \times 32.3$ & 2 & $\begin{array}{c}172 \\
\text { (per end) }\end{array}$ & 10 & $4-35$ & RF & Yes \\
\hline
\end{tabular}

fps, frames per second; RF, radiofrequency; EFP, electric field propagation; FDA, Food and Drug Administration.

The PillCam SB ${ }^{\circledR}$ (first generation; $11 \times 26 \mathrm{~mm}$ ) is equipped with one camera; it has a frame rate of 2 frames/s and a $140^{\circ}$ field-of-view. The second and third-generation PillCam $\mathrm{SB}^{\circledR}$ have the same size and number of cameras but the field-of-view is up to $156^{\circ}$. An adaptive frame rate system was added and compared to PillCam SB2 ${ }^{\circledR}$ (second generation), the resolution was improved by $30 \%$; moreover, the operating time was extended to $11 \mathrm{~h}$. In addition, it became possible to check the image of the capsule endoscope in real time through a real-time viewer. Intromedic (Seoul, South Korea) released MiroCam ${ }^{\circledR}$ in 2007, and unlike other capsule endoscopes, this transmits information using human body communication, which reduces power consumption, and enables video recording for a longer period. The recently developed MiroCam MC $4000^{\circledR}$ has two lenses at one side of the capsule that are displaced by approximately $4 \mathrm{~mm}$, four LED lights, a wireless transmitter, and a battery. The depth range is up to $30 \mathrm{~mm}$, the field-of-view is $170^{\circ}$ and the frame rate is $2 \times 2$ frames/s. MiroCam MC $4000^{\circledR}$ can perform size measurements and hardware-enabled 3D reconstruction using images from the two lenses. CapsoCam ${ }^{\circledR}$, launched in 2013 by Capso-Vision of the United States, stores captured images in the capsule endoscope; thus, an external receiver and a data recorder are not required during 
the examination. However, this capsule endoscope must be found in the patient's stool after the examination. In the CapsoCam design, four cameras were placed at $90^{\circ}$ intervals in the middle of the capsule to provide a $360^{\circ}$ field-of-view, and Capso-Cam SV- $1^{\circledR}$ can capture images at 12 to 20 frames/s. EndoCapsule ${ }^{\circledR}(11 \times 26 \mathrm{~mm})$, released by Olympus (Tokyo, Japan) in 2005, captures images at 2 frames/s and has up to $145^{\circ}$ field-of-view. The device self-adjusts its brightness and uses a high-resolution charge-coupled device lens to obtain an optimal image. The second-generation EndoCapsule ${ }^{\circledR}$ has a wider field-of-view $\left(160^{\circ}\right)$ and has an operating time of $12 \mathrm{~h}$, which is longer than that of the first generation EndoCapsule ${ }^{\circledR}$. OMOM Capsule ${ }^{\circledR}$, developed by Jinshan Science \& Technology in China, has a size of $11 \times 25.4 \mathrm{~mm}$, and the second-generation OMOM Capsule ${ }^{\circledR}$ has a wider field-of-view $\left(165^{\circ}\right)$ than the first generation, and the image quality is improved. This endoscope can capture images at 2 frames/s and has a battery life of about $10 \mathrm{~h}$.

\section{Diagnostic Yields of Small Bowel Capsule Endoscopy}

Table 2 shows a summary of the diagnostic yields of SBCE.

Table 2. Summary of diagnostic yield according to each indication of small bowel capsule endoscopy.

\begin{tabular}{|c|c|c|c|c|c|}
\hline Author, Year [Ref] & Country & Study Design & Study Period & $\begin{array}{l}\text { Number of } \\
\text { Patients }\end{array}$ & Results \\
\hline \multicolumn{6}{|c|}{ Obscure Gastrointestinal Bleeding } \\
\hline Teshima, 2011 [17] & Netherlands & meta-analysis & $\mathrm{N} / \mathrm{A}$ & $\begin{array}{l}10 \text { trials } \\
\text { (1239 patients) }\end{array}$ & $\begin{array}{l}\text { Diagnostic yield: SBCE } 61.7 \% \text { vs. } \\
\text { DBE } 55.5 \% \\
\text { Diagnostic yield for DBE after a } \\
\text { previously positive SBCE: } 75.0 \% \\
\text { Diagnostic yield for DBE after a } \\
\text { previously negative SBCE: } 27.5 \%\end{array}$ \\
\hline Kim, 2005 [18] & Korea & retrospective & $\mathrm{N} / \mathrm{A}$ & 21 & Diagnostic yield: $42.9 \%$ \\
\hline Jang, $2007[19]$ & Korea & retrospective & $2003-2005$ & 60 & $\begin{array}{c}\text { Diagnostic yield: SBCE } 65.7 \% \text { vs. } \\
\text { DBE } 80 \%\end{array}$ \\
\hline Lee, 2007 [20] & Korea & retrospective & $2002-2004$ & 126 & Diagnostic yield: $69 \%$ \\
\hline Ell, 2002 [21] & Germany & prospective & $2001-2001$ & 65 & $\begin{array}{l}\text { Diagnostic yield: SBCE } 66 \% \text { vs. } \\
\text { push-enteroscopy } 28 \%\end{array}$ \\
\hline Pennazio, 2004 [22] & Italy & prospective & $2001-2002$ & 100 & $\begin{array}{c}\text { Diagnostic yield } \\
\text { - ongoing overt bleeding: } 92.3 \% \\
\text { - previous overt bleeding: } 12.9 \% \\
\text { - guaiac-positive stools and } \\
\text { iron-deficiency anemia: } 44.2 \%\end{array}$ \\
\hline Lepileur, 2012 [23] & France & retrospective & $2004-2010$ & 911 & Diagnostic yield: $56 \%$ \\
\hline Leung, 2012 [24] & China & prospective & $2005-2007$ & 60 & $\begin{array}{c}\text { Diagnostic yield: SBCE 53\% vs. } \\
\text { angiography } 20 \%\end{array}$ \\
\hline Segarajasingam, 2015 [25] & Australia & prospective & $2006-2009$ & 79 & $\begin{array}{l}\text { Diagnostic yield: SBCE } 72.5 \% \text { vs. } \\
\text { push-enteroscopy } 48.7 \%\end{array}$ \\
\hline Laine, 2010 [26] & USA & $\mathrm{RCT}$ & $2003-2008$ & 136 & $\begin{array}{l}\text { Diagnostic yield: SBCE } 27 \% \text { vs. } \\
\text { small bowel radiography } 4 \%\end{array}$ \\
\hline \multicolumn{6}{|c|}{ Small Bowel Tumor \& Inherited Polyposis Syndrome } \\
\hline Han, 2015 [27] & Korea & retrospective & 2004-2012 & 79 & $\begin{array}{c}\text { Diagnostic yields: CT } 55.8 \% \text { vs. } \\
\text { SBFT } 46.1 \% \text { vs. SBCE } 83.3 \% \\
\text { Sensitivity: CT } 40.4 \% \text {, vs. SBFT } \\
43.9 \% \text { vs. SBCE } 79.6 \%\end{array}$ \\
\hline Schulmann, 2005 [28] & Germany & prospective & $\mathrm{N} / \mathrm{A}$ & 40 & $\begin{array}{l}\text { Diagnostic yield in patients } \\
\text { with PJS: } 90.9 \%\end{array}$ \\
\hline
\end{tabular}


Table 2. Cont.

\begin{tabular}{|c|c|c|c|c|c|}
\hline Author, Year [Ref] & Country & Study Design & Study Period & $\begin{array}{l}\text { Number of } \\
\text { Patients }\end{array}$ & Results \\
\hline Iaquinto, 2008 [29] & Italy & prospective & $\mathrm{N} / \mathrm{A}$ & 23 & $\begin{array}{c}\text { Diagnostic yield in patients } \\
\text { with FAP: } 30.4 \%\end{array}$ \\
\hline \multicolumn{6}{|c|}{ Crohn's Disease } \\
\hline Dionisio, 2010 [30] & USA & meta-analysis & $\mathrm{N} / \mathrm{A}$ & $\begin{array}{c}12 \text { trials } \\
\text { (428 patients) }\end{array}$ & $\begin{array}{c}\text { Diagnostic yield for suspected } \\
\text { Crohn's disease } \\
\text {-SBCE } 52 \% \text { vs. SBR } 16 \% \\
\text {-SBCE } 68 \% \text { vs. CTE } 21 \% \\
\text {-SBCE } 47 \% \text { vs. ileocolonoscopy } 25 \% \\
\text { Diagnostic yield for established } \\
\text { Crohn's disease } \\
\text {-SBCE } 71 \% \text { vs. SBR } 36 \% \\
\text {-SBCE } 66 \% \text { vs. push-enterography } \\
9 \% \\
\text {-SBCE } 71 \% \text { vs. CTE } 39 \%\end{array}$ \\
\hline Jensen. 2011 [31] & Denmark & prospective & 2007-2009 & 93 & $\begin{array}{c}\text { The sensitivity and specificity for } \\
\text { diagnosis of Crohn's disease of } \\
\text { the TI } \\
\text {-SBCE: } 100 \% \text { and } 91 \% \\
\text {-MRE: } 81 \% \text { and } 86 \% \\
\text {-CTE: } 76 \% \text { and } 85 \%\end{array}$ \\
\hline Kharazmi, 2020 [32] & Denmark & retrospective & 2011-2018 & 516 & Diagnostic yield: $50 \%$ \\
\hline Mehdizadeh, 2010 [33] & USA & retrospective & 2001-2005 & 134 & Diagnostic yield: $52 \%$ \\
\hline \multicolumn{6}{|c|}{ Celiac Disease } \\
\hline Lujan-Sanchis M, 2017 [34] & Spain & retrospective & $2003-2015$ & 163 & Diagnostic yield: $54 \%$ \\
\hline
\end{tabular}

SBCE, small bowel capsule endoscopy; DBE, double balloon enteroscopy; SBR, small bowel radiography; CTE, computed tomographic enterography; MRE, magnetic resonance enterography; PJS, Peutz-Jeghers Syndrome; FAP, familial adenomatous polyposis; N/A, not applicable.

\subsection{Small Bowel Bleeding}

OGIB is a commonly encountered clinical issue in gastroenterology and is associated with significant morbidity and mortality. OGIB originates in the small bowel in more than $80 \%$ of cases and is associated with vascular abnormalities, gastrointestinal tumors, and conditions such as Meckel diverticulum and CD [35]. Localization of small bowel bleeding is tedious for gastroenterologists due to the complex loops and long length of the small bowel. However, recent advances in imaging technology have changed the paradigm. Understanding the advantages and limitations, diagnostic yield, and therapeutic capabilities of these tests can help clinicians determine the most appropriate choice.

In the past, most cases of OGIB were not readily accessible for diagnosis and treatment, and occasionally, surgery or intraoperative endoscopy was required. However, with the active use of SBCE and balloon-assisted enteroscopy (BAE) in the recent years, it has become possible to identify the OGIB source in the gastrointestinal tract in most cases [36-38]. The diagnostic yield of SBCE for OGIB is 27-92.3\% [17-25]. In three randomized controlled trials involving patients with OGIB and negative findings on esophagoduodenoscopy and ileocolonoscopy, the diagnostic yield of CE was significantly higher than those of SBR (27\% vs. $4 \%$; difference, $23 \%$; $95 \%$ confidence interval [CI], 5-42) [26], angiography (53\% vs. $20 \%$; difference, $33 \%$; $95 \%$ CI, 9-53; $p=0.016)$ [24], and push-enteroscopy (72.5\% vs. $48.7 \% ; p=0.03$ ) [25]. CTE (computed tomographic enterography) has a good diagnostic yield in the evaluation of patients with small bowel diseases. However, CTE is limited in its evaluation of OGIB and is relatively insensitive for small, infiltrative, flat, or inflammatory bleeding lesions of the small bowel [39]. According to a large-scale metaanalysis on CTE results for OGIB (18 studies; 660 patients), CTE showed a 40\% (95\% CI: 33-49) diagnostic yield for OGIB. In seven studies, the diagnostic yield of CTE vs. SBCE was 
$34 \%$ vs. $53 \%$ (95\% CI: -34 to -4$)$. In two studies (63 patients), the diagnostic yield of CTE vs. DBE was 38\% vs. 78\% (95\% CI: -55 to -25) [40]. Other imaging techniques, such as radioisotope bleeding scan and angiography, were also insensitive in the absence of massive bleeding (rate of bleeding, $\geq 0.5 \mathrm{~mL} / \mathrm{min}$ ) [41,42].

In OGIB patients, the diagnostic yield of CE was similar to those of BAE and intraoperative enteroscopy $[9,17,43]$. However, BAE is invasive and time-consuming; general anesthesia is required in most cases, making it technically challenging to explore the entire small bowel. In contrast, SBCE is noninvasive, very well tolerated, and easy to perform [8,9]. In a meta-analysis on OGIB (10 published studies involving 651 patients), there was no statistically significant difference in diagnostic yield between $\mathrm{CE}$ and DBE (62\% for CE vs. 56\% for DBE; 95\% CI, 0.64-2.29) [17]. Similar to the results of meta-analyses in the literature, the diagnostic yield for OGIB was 42.9-69\% in Korean studies [18-20]. The diagnostic yield of DBE for CE-confirmed OGIB lesions was 75\%, which was significantly higher than the yield when only DBE was performed (56\%) (odds ratio, 1.79). Therefore, the diagnostic yield of DBE is better when DBE is performed after CE [17]. Thus, in a large group of patients with OGIB, DBE should be considered in a highly selected group, while $\mathrm{CE}$ can serve as a preliminary diagnostic tool in patients with small bowel bleeding.

The factor that most affects the diagnostic yield in OGIB is the bleeding status. The diagnostic yield is significantly increased when the examination is performed in the presence of active/occult bleeding [22,23]. Positive findings on CE were obtained in $92.3 \%$ of patients with ongoing overt bleeding, $12.9 \%$ in patients with previous overt bleeding, and $44.2 \%$ in patients with guaiac-positive stools and iron deficiency anemia [22]. In a large-scale retrospective cohort study, performing CE early after admission was associated with a higher diagnostic yield (55\% on day $1,48 \%$ on day $2,29 \%$ on day $3,27 \%$ on day 4 , and $18 \%$ on day 5) [44]. According to Korean Gut Image Study Group (KASID) guidelines concerning OGIB published in 2013, CE is an effective initial diagnostic method for evaluating patients. Diagnostic yield is improved when CE is performed early in OGIB [45]. The 2015 European Society of Gastrointestinal Endoscopy (ESGE) guidelines also recommend SBCE be performed as soon as possible after a bleeding episode (within 14 days), in patients with OGIB [11]. Therefore, SBCE should be performed as early as possible after bleeding is identified. In addition, the diagnostic yield for OGIB was dependent on age, warfarin use, underlying liver disease, number of previous esophagogastroduodenoscopies, amount of blood transfusion required, and presence of connective tissue disease [46-48].

\subsection{Small Bowel Tumor}

Malignant neoplasms of the small bowel are among the rarest types of cancer, accounting for $1-2 \%$ of all gastrointestinal cancers [49]. Diagnosis of small bowel tumors via SBCE can be challenging. The clinical manifestations of small bowel tumors tend to be nonspecific, which can delay diagnosis, especially in the early stages. After the development of $\mathrm{CE}$, the incidence of small bowel tumors increased to $2-10 \%[50,51]$.

In a recent retrospective study, the diagnostic yield of SBCE was $83.3 \%$ for small bowel tumors, whereas those for CT and SBFT were $55.8 \%$ and $46.1 \%$, respectively. Sensitivity for detecting small bowel tumors was $40.4 \%$ for CT, $43.9 \%$ for SBFT, and $79.6 \%$ for SBCE [27]. Conclusively, it is considered that the diagnostic yield of SBCE is sufficient for the diagnosis and evaluation of small bowel tumors. However, the risk of false-negative SBCE results should always be considered, and this is more frequent for small bowel tumors and polyps in the duodenum and proximal jejunum, and submucosal tumors where a mucosal component is absent, such as gastrointestinal stromal tumors or neuroendocrine tumors [11]. In addition, the diagnosis rate of SBCE might be lower than that of CT or magnetic resonance imaging because SBCE cannot evaluate extraluminal status [52]. In this situation, magnetic resonance enterography (MRE) had higher specificity than SBCE, and CTE had higher sensitivity than SBCE [53,54]. Furthermore, the analysis of SBCE findings varies among interpreters; false-positive results are occasionally included. A scoring system that includes five reading components (bleeding, irregular surface, mu- 
cosal disruption, white villi, and color) of SBCE findings was proposed to overcome this shortcoming [55]. A prospective study evaluated SPICE (smooth, protruding lesion index on capsule endoscopy) score. The score has the following criteria for smooth protruding lesions: diameter larger than height, ill-defined boundary with the surrounding mucosa, non-visible lumen in the frames in which the lesion appears, and an image lasting less than $10 \mathrm{~min}$. The score had a specificity of $89 \%$ and a sensitivity of $83 \%$ [56]. Further larger prospective studies are needed to validate such scoring systems.

Caution is required during examination since capsule retention may occur due to the presence of small bowel tumor. However, in the case of malignant tumors, capsule retention may serve as a marker of lesion location, which may be advantageous therapeutically [57].

\subsection{Inherited Polyposis Syndrome}

Intestinal polyposis syndromes are relatively rare. Intestinal polyposis syndromes can be divided, based on histology, into broad categories of familial adenomatous polyposis (FAP), hamartomatous polyposis syndromes (mainly including Peutz-Jeghers Syndrome (PJS), PTEN-associated hamartomatous syndromes, Cronkhite-Canada syndrome, and familial juvenile polyposis), and other rare polyposis syndromes such as serrated polyposis syndrome and hereditary mixed polyposis syndrome.

Prior to the development of SBCE, the diagnosis of small bowel polyposis was via SBR. It is difficult to access the tumor through a conventional endoscope when small bowel polyps are diagnosed using SBR. Thus, surgery or endoscopic polypectomy during surgery was performed. However, with the recent development of SBCE and BAE, SBCE is reported to have a higher sensitivity than SBR in diagnosing small bowel polyps in inherited polyposis syndrome [58]. The detection rate of SBCE for jejunal-ileal polyp is $24-30 \%$ in FAP patients and $90 \%$ (10 of 11 patients) in PJS patients $[28,29]$. Thus, small bowel polyp, which is difficult to access with a conventional endoscope, can be removed through BAE without surgery [59].

It is difficult to evaluate the duodenum, ampulla, and size of polyps through SBCE. A study reported that SBCE could detect duodenal polyps in only $36.4 \%$ of patients with endoscopically identified FAP [29]. Therefore, conventional endoscopic devices are recommended to evaluate the proximal small bowel in patients with FAP [11]. However, as more than $75 \%$ of patients with FAP and PJS have small bowel polyps and the risk of small bowel polyp increases with the presence of a duodenal polyp, SBCE can be considered when small bowel investigation is clinically required $[28,60,61]$.

In a study by Burke et al., small bowel polyps were observed in $60 \%$ of FAP cases and $75 \%$ of PJS cases through SBCE examination, and the treatment plan was changed in $50 \%$ of patients. Therefore, the role of SBCE in detecting inherited polyposis syndrome is expanding [60]. However, it is important to note that occasionally, SBCE may miss a large polyp. Several studies have reported that MRE could detect large polyps (>15 $\mathrm{mm}$ ) better than $\mathrm{CE}$, and compared to $\mathrm{CE}$, the result of MRE is more reproducible [60,62-64]. $\mathrm{SBCE}$ is recommended for small bowel surveillance in patients with polyposis syndrome, especially in patients with PJS, who are at high risk of intussusception and bleeding related to small bowel polyps $[11,61]$.

\subsection{Crohn's Disease}

$\mathrm{CD}$ is a chronic, progressive inflammatory bowel disease that can affect any segment of the gastrointestinal tract but commonly involves the small bowel in up to $60 \%$ of cases [65]. Small bowel CD is associated with serious complications such as stricture, abscess, and obstruction $[66,67]$. Small bowel CD has been underestimated due to diagnostic limitations in visualizing the small bowel $[68,69]$. CD is diagnosed by combining clinical features (abdominal pain or diarrhea for more than 6 weeks), laboratory test results (such as $C$-reactive protein level, fecal calprotectin level, and anemia or hypoalbuminemia), radiologic imaging, endoscopic evaluation, and histologic findings. Conventional diagnostic tools such as SBR, push-enteroscopy, and ileocolonoscopy have been used for small bowel CD, but these 
tools are limited by the difficult test procedure and the impossibility of detailed direct observation of intraluminal lesions. ESGE and Canadian guidelines suggest that CE is the initial diagnostic tool for assessing pathognomic symptoms of CD in the presence of a negative ileocolonoscopy examination and in the absence of obstructive symptoms or radiologic stenosis [11,61]. In addition, SBCE is recommended in patients with established $\mathrm{CD}$, who have unclear clinical features on ileocolonoscopy or cross-sectional imaging, and in patients with established CD to confirm small intestinal mucosal healing.

In $C D$, examination of the terminal ileum during ileocolonoscopy may be important for diagnosis. However, the disadvantage of ileocolonoscopy is that only a part of the distal terminal ileum can be observed, and if the colon is stenosed, the scope cannot reach the cecum or intubation to the ileum. In addition, push-enteroscopy can be used to observe only $80-120 \mathrm{~cm}$ beyond the ligament of Treitz, and there are many complications: thus, there is a limit to its use [70]. SBFT is the most traditional method for obtaining images for small bowel evaluation in CD patients, but the patient is exposed to radiation and the diagnostic accuracy is related to the examiner's experience [71]. In patients with suspected CD, the diagnostic yield of SBFT was only approximately $35 \%$, whereas the diagnostic yield of SBCE was 70\% [72]. Furthermore, although CTE has high diagnostic sensitivity, it cannot visualize lesions directly, whereas SBCE can visualize subtle changes in the entire small bowel mucosa. In other studies, in patients with a negative or inconclusive conventional workup (including ileocolonoscopy, CTE/MRE, or SBR) to diagnose CD, SBCE showed good sensitivity (93\%) and specificity (84\%) [73], and SBCE led to an incremental diagnostic yield of $24 \%$ [74]. Therefore, SBCE can confirm the presence of a lesion in the small intestinal mucosa in patients with suspected CD and in patients with known ileal and colonic CD; moreover, extensive small bowel involvement in CD can be evaluated.

According to a meta-analysis of 19 trials, when SBCE was performed in patients with suspected CD, its diagnostic yield was significantly higher than that of SBR, colonoscopy with ileoscopy (C + IL), and CTE (CE vs. SBR: 52\% vs. $16 \%$; 95\% CI, 16-48; $p<0.00001$, CE vs. CTE: $68 \%$ vs. $21 \%$; 95\% CI, 31-63; $p=0.009$, CE vs. C + IL: $47 \%$ vs. $25 \%$; $95 \%$ CI, $5-39 ; p<0.00001)$. However, no statistical difference was found in diagnostic yield in the meta-analysis between CE and MRE in cases of suspected SBCD (CE, 55\% vs. MRE, 45\%; incremental yield, $10 \%$; 95\% CI, 14-34; $p=0.43$ ) [30]. In the literature, compared to MRE, SBCE showed equal or superior diagnostic yield $[31,75,76]$. In addition, when the analysis was performed in a real-world setting, the diagnostic yield of SBCE for CD was 50\% [32].

In a study by Solem et al., the sensitivity and specificity of SBFT, ileocolonoscopy, CTE, and SBCE were compared in 41 patients with suspected or established CD. Test accuracy was $86 \%$ for ileocolonoscopy, $85 \%$ for CTE, $79 \%$ for SBFT, and $67 \%$ for SBCE. When the two tests were combined, SBCE and other small bowel imaging tests showed the highest sensitivity (92-100\%) [77]. In symptomatic patients with an established diagnosis of CD, the diagnostic yield of SBCE was good (approximately 50\%) [33]. However, CTE is more useful than SBCE in more advanced CD, such as bowel obstruction, fistula, and abscess [78]. In a prospective study by Gralnek et al., SBCE often led to a definitive diagnosis of CD, and $\mathrm{CE}$ influenced decision making in $72 \%$ of patients and led to a change in management in $78 \%$ of patients [79].

In evaluating recurrence in patients with $C D$ who underwent surgery, SBCE showed superior yield than ileocolonoscopy (62\% vs. $25 \%)$, with the advantage of detecting proximal small bowel lesions. It is difficult to pass a surgical anastomosis and observe the proximal part by ileocolonoscopy in patients who underwent side-to-side reconstitution of a neoiluem, which is why CE is more useful [80].

Before applying SBCE in CD, it is necessary to note the stenotic characteristic of CD. In the case of the small bowel, there may be no symptoms of obstruction until the lumen is almost blocked, because easy passage of liquid substances is retained in the stenotic situation. Therefore, although the capsule endoscope is small, it can be retained in the stenosis for a long time or cause complete occlusion. If this obstruction requires open surgery, it will pose a great threat to patients with stenosis [81]. Even if the endoscope 
passes through the stenosis if it takes much time to pass the stenosed area, the distal part of the stenosis may not be visualized due to battery exhaustion. Another limitation of SBCE is that it can be difficult to locate small intestinal lesions, and it takes $1-2 \mathrm{~h}$ to read the input image properly [82]. However, despite these limitations, it seems clear that SBCE can be added as a new tool for evaluating small bowel involvement in CD.

\subsection{Celiac Disease}

Celiac disease is an autoimmune, gluten-induced small bowel enteropathy. Anti-tissue transglutaminase and anti-endomysial antibodies are used as serological diagnostic markers for celiac disease. Evaluating an individual's response to a gluten-free diet is also a diagnostic method. However, the most important diagnostic approach is to confirm the presence of villous atrophy in the duodenum and small bowel via esophagogastroduodenoscopic biopsy. According to a meta-analysis, the sensitivity of CE in celiac disease was $89 \%$ (95\% CI, 82-94) and the specificity was 95\% (95\% CI, 89-98). However, when the patient tests positive for anti-tissue transglutaminase and anti-endomysial antibodies, the positive predictive value and specificity of the endoscopic markers for celiac disease are $100 \%$ [11]. In a case of suspected celiac disease, the diagnostic yield was approximately $54 \%$ [34], but in general, CE is not recommended for suspected celiac disease. However, if there is no response to the appropriate treatment, CE should be considered, to differentiate other etiologies and evaluate the complications of celiac disease. Particularly, it is important to differentiate refractory celiac disease because of the associated risk of intestinal T-cell lymphoma. CE had higher concordance than optic endoscopy for histology of villous atrophy in refractory celiac disease ( $\kappa$ coefficient $=0.45$ vs. $0.24, p<0.001$ ), and extensive mucosal damage observed on CE was correlated with patient nutritional status $(p=0.003)$. Additionally, extensive mucosal damage observed on CE could predict the type of refractory celiac disease (refractory celiac disease type II) [83]. Conversely, refractory celiac disease type I showed low diagnostic yield in imaging procedures, including CE [84]. A review of the literature revealed that most studies related to celiac disease included a small number of subjects; thus, additional studies are needed in the future.

\section{Current Status of Colon Capsule Endoscopy}

In 2006, first-generation CCE was initially released by Given Imaging (PillCam ${ }^{\circledR}$ COLON, Given Imaging (eventually purchased by Medtronic), Yokneam, Israel) [85]. CCE-1 (PillCam COLON ${ }^{\circledR}$, first-generation; $11 \times 31 \mathrm{~mm}$ in size) is equipped with two cameras; it has a frame rate of 4 frames $/ \mathrm{s}$ and a $156^{\circ}$ field-of-view on both sides. A prospective study with CCE-1 showed that the sensitivity of CCE-1 for detecting colonic lesions was low compared to colonoscopy and the results were unsatisfactory (low sensitivity for detection of colon polyps (64\%), advanced adenomas (73\%), and colorectal cancers (74\%)) [86]. As a result, second-generation CCE-2 (PillCam COLON ${ }^{\circledR}$, second generation; $11.6 \times 31.5 \mathrm{~mm}$ in size) was developed to achieve higher sensitivity in 2014. CCE-2 has two high-resolution cameras providing the field-of-view of $172^{\circ}$ for each camera, allowing a nearly full visual coverage of the colonic mucosa [87]. It has been endowed with a battery lasting about $10 \mathrm{~h}$ and has an adaptive frame rate system (setting the frame rate to 4 or 35 frames/s). Thus, a prospective European multicenter study demonstrated that the detection rate of colon polyps of $>5 \mathrm{~mm}$ using CCE-2 was almost equivalent to colonoscopy [88].

\section{Diagnostic Yield of Colon Capsule Endoscopy}

CCE is safe and feasible for obtaining sufficient colonic images without obstruction in patients who underwent incomplete colonoscopy [89]. Recent publications have indicated CCE investigations as feasible after incomplete colonoscopy [16,90,91]. Further, studies have indicated patients' preference for CCE compared to colonoscopy [92,93], and the complication rates of CCE are very low [12-16]. The success rate of CCE is reported to be $68-98 \%$ [12-16]. Table 3 shows a summary of the diagnostic yield of CCE. 
Table 3. Summary of diagnostic yield of colon capsule endoscopy.

\begin{tabular}{cccccc}
\hline Author, Year [Ref] & Country & Study Design & Study Period & $\begin{array}{c}\text { Number of } \\
\text { Patients }\end{array}$ & Results \\
\hline Otani, 2020 [13] & Japan & retrospective & $2011-2017$ & 60 & $\begin{array}{c}\text { Diagnostic yield (for polyp larger than } \\
6 \text { mm): 56.7\% }\end{array}$ \\
\hline Hussey, 2018 [14] & Ireland & prospective & $2015-2017$ & 50 & $\begin{array}{c}\text { Diagnostic yield (new lesions after } \\
\text { incomplete colonoscopy): 74\% }\end{array}$ \\
\hline Nogales, 2017 [15] & Spain & prospective & $2010-2013$ & 96 & $\begin{array}{c}\text { Diagnostic yield (new lesions after } \\
\text { incomplete colonoscopy): 60.4\% }\end{array}$ \\
\hline Baltes, 2018 [90] & Germany & prospective & $2010-2013$ & 74 & $\begin{array}{c}\text { Diagnostic yield (for significant polyp * } \\
\text { including adenocarcinoma): 28\% }\end{array}$ \\
\hline Negreanu, 2013 [93] & Romania & prospective & N/A & 70 & Diagnostic yield (any finding): 34\% \\
\hline Pioche, 2012 [94] & France & prospective & $2008-2009$ & 107 & $\begin{array}{c}\text { Diagnostic yield (new lesions after } \\
\text { incomplete colonoscopy): 33.6\% }\end{array}$ \\
\hline Alarcon, 2013 [95] & Spain & prospective & $2010-2011$ & 34 & $\begin{array}{c}\text { Diagnostic yield (any finding): 34\% } \\
\text { Efficacy of CCE (allowing formulation } \\
\text { of a specific medical plan): 58.8\% }\end{array}$ \\
\hline
\end{tabular}

* Significant polyp, defined by size ( $\geq 6 \mathrm{~mm})$ or number $(\geq 3)$; N/A, not applicable.

In a multicenter large-scale cohort study conducted in the Netherlands in 2005, $9.7 \%$ (511/5278 patients) of colonoscopy examinees underwent incomplete colonoscopy. Non-advanced adenoma was found in unexplored colon segments in $2.3 \%$ of patients, advanced adenoma in $0.8 \%$, and colorectal cancer in $3.5 \%$ [96]. In a study on the diagnostic yield and relative sensitivity of CCE, compared to those of CT colonography (CTC), after incomplete colonoscopy, the diagnostic yield for polyps $\geq 5 \mathrm{~mm}$ for CCE vs. CTC was $41.24 \%$ (95\% CI, 31.34-51.69) vs. $15.46 \%$ (95\% CI, 8.92-24.22), and the relative sensitivity of CCE was 2.67 (95\% CI, 1.76-4.04). Further, the diagnostic yield for polyps $\geq 9 \mathrm{~mm}$ for CCE was $21.65 \%$ (95\% CI, 13.93-31.17), while that for CTC was $11.34 \%$ (95\% CI, $5.80-19.39)$, and the relative sensitivity of CCE was 1.91 (95\% CI, 1.18-3.09) [12]. In addition, in a prospective, comparative study that compared CCE and CTC in patients who underwent incomplete colonoscopy, the per-patient sensitivity of CCE compared to CTC was 2.0 (95\% CI, 1.34-2.98) for polyps $\geq 6 \mathrm{~mm}$ and 1.67 (95\% CI, 0.69-4.00) for larger polyps ( $\geq 10 \mathrm{~mm}$ ) [16]. Therefore, the overall diagnostic yield of CCE was superior to that of CTC. Capsule retention may occur in $1.4-2 \%$ of cases, and the cause may include ileal stricture due to unknown CD without symptoms and inflammatory stricture related to non-steroidal anti-inflammatory drug use $[14,90]$.

\section{Clinical Impact}

SBCE has an important clinical impact on further diagnostic workup, therapeutic strategy, and long-term clinical evaluation in patients with OGIB, with favorable outcomes. According to Katsinelos et al., in patients with OGIB, the management plan was changed, according to SBCE findings; SBCE findings in 45 out of 63 patients $(71.43 \%)$ led to the introduction of a therapy that resolved the underlying disease or improved the clinical condition during long-term follow-up (11.8 \pm 8.7 months) [97]. In another study, SBCE findings $(66.3 \%, 61$ of 92 patients) showed the absence of overt bleeding and a normal hemoglobin value, and a 100\% resolution of OGIB in young adults ( $<50$ years old) was observed in the long-term follow up (range 81-1348 days) [98]. A negative SBCE finding was associated with a low risk of recurrent bleeding, and a significant abnormal finding was an independent predictor of recurrent bleeding. (HR $=2.4,95 \% \mathrm{CI}, 1.1-5.8)[99,100]$. Further, although SBCE showed negative findings related to OGIB, it detected other digestive lesions and had an indirect clinical impact [101]. Although there are cases of small bowel tumors causing OGIB (or iron deficiency anemia), there are also cases of small bowel mass or polyp causing OGIB, based on SBCE findings. Additionally, guidelines recommend early use of 
SBCE to evaluate small bowel tumors when the cause of OGIB and iron deficiency anemia is unknown [11].

SBCE can identify lesions compatible with suspected CD, with the consequent change in treatment options for patients. Usually, the diagnostic delay from the onset of CD to diagnosis can be up to 7 years [102,103]. In the past, differential diagnosis of CD from tuberculosis, celiac disease, or Bechet's disease was very difficult, but the introduction of SBCE has been helpful in determining diagnosis. If differential diagnosis is difficult, follow-up SBCE may be performed to evaluate the healing status of the mucosa after treatment. SBCE which was performed to evaluate OGIB enables early diagnosis of CD, allowing early initiation of treatment. Moreover, since CD with bleeding is often in the active phase, it may be associated with the early use of biologics. Urgesi et al. reported that findings indicative of CD were confirmed in 19.1\% (94 of 492 patients) of patients who underwent SBCE for suspected OGIB. Subsequently, the diagnosis was confirmed during follow-up among these patients in whom CD was detected via SBCE [104]. SBCE can alter management plans in up to a third of patients with CD [105]. The jejunal involvement in CD is associated with a significant risk of further clinical relapse, stricture disease, and multiple abdominal surgeries, and SBCE enables the determination of disease prognosis [106]. Thus, identifying the proximal small bowel via lesions detected on SBCE has enhanced medical management. Mucosal healing can be evaluated by SBCE to monitor the effect of medical treatment in patients with $C D$, with a significant correlation between the Lewis score and fecal calprotectin [107]. SBCE is also used to diagnose recurrences of CD after surgery, and CE might increase diagnostic accuracy and impact therapeutic decisions [80]. Finally, it is necessary to consider the active use of SBCE in the treatment and assessment of treatment response in patients with $\mathrm{CD}$.

SBCE also has a significant impact on celiac disease. Since positive endoscopic SBCE finding in patients with positive endomysial antibody/transglutaminase antibody has high specificity [11], SBCE can be used as a good diagnostic tool in patients who are unable to undergo esophagogastroduodenoscopy [108]. In newly detected uncomplicated celiac disease, atrophy is usually confined to the proximal small bowel on SBCE, and this may indicate a favorable outcome [109]. In addition, SBCE can be used to assess complicated diseases, such as malignancy or ulceration, when the clinical course of the disease shows progressive worsening, even in the presence of treatment and a gluten-free diet. In this case, performing CTE/MRE with SBCE may be helpful [110].

When reviewing the clinical impact of CCE on medical decision making in patients who underwent incomplete colonoscopy, it was found that the treatment plan was changed in 5.7-56.6\% of cases (colectomy, colorectal cancer operation, and therapeutic colonoscopy and polypectomy were performed in $0.9-1.3 \%, 2-5.7 \%$, and $17.6-56.6 \%$ of cases, respectively) [12-16,94,95]. Further, in 5-15\% of patients undergoing colonoscopy, the scope may not be able to reach the cecum due to the severe pain, severe mesenteric redundancy, and postoperative adhesions [111]. Therefore, in elderly individuals, women, and patients with a history of abdominal or pelvic surgery, in whom there is a likelihood of incomplete colonoscopy, CCE can be alternatively considered [112]. In addition, it is important for patients with FAP to undergo colorectal cancer screening at least every 2 years from the age of 10-12. An advantage of CCE is that it can reduce the risk of colonoscopy-related complications, such as perforation, and it can be performed in children and adolescents who are at high risk of developing colorectal cancer but refuse to undergo colonoscopy due to the associated discomfort [113].

\section{Conclusions}

Since the introduction of SBCE in clinical practice in 2001, SBCE has been improved to include a wider field-of-view, high-resolution imaging, longer battery life, and miniaturization; thus, the clinical application of CE is gradually expanding. SBCE has proven a high diagnostic yield and is often the preferred initial diagnostic test in patients with OGIB, who have known or suspected CD, small bowel tumor, and inherited polyposis syndrome 
because of its noninvasive quality, better tolerance, and ability to view the entire small bowel. CCE is also considered safe and feasible for obtaining sufficient colonic images in patients with incomplete colonoscopy, with possible use in colorectal screening.

CE is currently available only as a diagnostic tool and still has limitations; future capsule prototypes seem necessary. Three-dimensional reconstruction of high-resolution imaging, high-frame-rate imaging, full spherical imaging, and capsule chromoendoscopy can reduce unnecessary invasive examination by clarifying the endoscopic and microscopic characteristics of small bowel lesions [114,115]. Controlling the movement of the capsule endoscope enables complete observation of the small bowel mucosa (without blind spots), thereby increasing the diagnosis rate of lesions [116]. Furthermore, CE is considered a therapeutic endoscope for biopsies, hemostasis, and drug delivery [117]. In addition, using computer-assisted diagnosis and artificial intelligence, CE reading could be achieved, reducing reading time and improving diagnosis [118,119]. With the development of these technologies, it is expected to be used in clinical applications as actual products in the near future.

Author Contributions: Conceptualization, D.H.B.; Data collection and curation, S.M.H. and S.H.J.; writing—original draft preparation, S.M.H. and S.H.J.; writing—review and editing, S.H.J. and D.H.B.; supervision, D.H.B. All authors have read and agreed to the published version of the manuscript.

Funding: This work was supported by a National Research Foundation of Korea (NRF) grant funded by the Korea government (MSIT) (No. 2019R1G1A1100749).

Data Availability Statement: Not applicable.

Conflicts of Interest: The authors declare no conflict of interest.

\section{References}

1. Antao, B.; Bishop, J.; Shawis, R.; Thomson, M. Clinical Application and Diagnostic Yield of Wireless Capsule Endoscopy in Children. J. Laparoendosc. Adv. Surg. Tech. 2007, 17, 364-370. [CrossRef]

2. Weaver, L.T.; Austin, S.; Cole, T. Small intestinal length: A factor essential for gut adaptation. Gut 1991, 32, 1321-1323. [CrossRef] [PubMed]

3. Yamamoto, H.; Kita, H. Enteroscopy. J. Gastroenterol. 2005, 40, 555-562. [CrossRef]

4. Costamagna, G.; Shah, S.K.; Riccioni, M.E.; Foschia, F.; Mutignani, M.; Perri, V.; Vecchioli, A.; Brizi, M.G.; Picciocchi, A.; Marano, P. A prospective trial comparing small bowel radiographs and video capsule en-doscopy for suspected small bowel disease. Gastroenterology 2002, 123, 999-1005. [CrossRef]

5. Van Gossum, A.; Hittelet, A.; Schmit, A.; Francois, E.; Deviere, J. A prospective comparative study of push and wireless-capsule enteroscopy in patients with obscure digestive bleeding. Acta Gastroenterol. Belg. 2003, 66, 199-205. [CrossRef]

6. Iddan, G.; Meron, G.; Glukhovsky, A.; Swain, P. Wireless capsule endoscopy. Wireless capsule endoscopy. Nature 2000, $405,417$. [CrossRef] [PubMed]

7. Yamamoto, H.; Sekine, Y.; Sato, Y.; Higashizawa, T.; Miyata, T.; Iino, S.; Ido, K.; Sugano, K. Total enteroscopy with a nonsurgical steerable double-balloon method. Gastrointest. Endosc. 2001, 53, 216-220. [CrossRef]

8. Chen, X.; Ran, Z.H.; Tong, J.L. A meta-analysis of the yield of capsule endoscopy compared to double-balloon enteroscopy in patients with small bowel diseases. World J. Gastroenterol. 2007, 13, 4372-4378. [CrossRef]

9. Pasha, S.F.; Leighton, J.A.; Das, A.; Harrison, M.E.; Decker, G.A.; Fleischer, D.E.; Sharma, V.K. Double-Balloon Enteroscopy and Capsule Endoscopy Have Comparable Diagnostic Yield in Small-Bowel Disease: A Meta-Analysis. Clin. Gastroenterol. Hepatol. 2008, 6, 671-676. [CrossRef]

10. Liao, Z.; Gao, R.; Xu, C.; Li, Z.-S. Indications and detection, completion, and retention rates of small-bowel capsule endoscopy: A systematic review. Gastrointest. Endosc. 2010, 71, 280-286. [CrossRef] [PubMed]

11. Pennazio, M.; Spada, C.; Eliakim, R.; Keuchel, M.; May, A.; Mulder, C.J.; Rondonotti, E.; Adler, S.N.; Albert, J.; Baltes, P.; et al. Small-bowel capsule endoscopy and device-assisted enteroscopy for diagnosis and treatment of small-bowel disorders: European Society of Gastrointestinal Endoscopy (ESGE) Clinical Guideline. Endoscopy 2015, 47, 352-386. [CrossRef] [PubMed]

12. Deding, U.; Herp, J.; Havshoei, A.L.; Kobaek-Larsen, M.; Buijs, M.M.; Nadimi, E.S.; Baatrup, G. Colon capsule endoscopy versus CT colonography after incomplete colonoscopy. Ap-plication of artificial intelligence algorithms to identify complete colonic investigations. United Eur. Gastroenterol. J. 2020, 8, 782-789. [CrossRef] [PubMed]

13. Otani, I.; Oka, S.; Tanaka, S.; Iio, S.; Tsuboi, A.; Kunihara, S.; Hiyama, Y.; Chayama, K. Diagnostic Yield of Colon Capsule Endoscopy in Detection of Superficial Colorectal Lesions. Digestion 2019, 101, 262-269. [CrossRef] 
14. Hussey, M.; Holleran, G.; Stack, R.; Moran, N.; Tersaruolo, C.; McNamara, D. Same-day colon capsule endoscopy is a viable means to assess unexplored colonic segments after incomplete colonoscopy in selected patients. United Eur. Gastroenterol. J. 2018, 6, 1556-1562. [CrossRef]

15. Nogales, O.; García-Lledó, J.; Luján, M.; Nicolás, D.; Juanmartiñena, J.F.; González-Suárez, B.; Ceballos, F.S.; Couto, I.; Olmedo, J.; Garfia, C.; et al. Therapeutic impact of colon capsule endoscopy with PillCam? COLON 2 after incomplete standard colonoscopy: A Spanish multicenter study. Rev. Española Enferm. Digestivas 2017, 109, 322-327. [CrossRef] [PubMed]

16. Spada, C.; Hassan, C.; Barbaro, B.; Iafrate, F.; Cesaro, P.; Petruzziello, L.; Minelli Grazioli, L.; Senore, C.; Brizi, G.; Costamagna, I.; et al. Colon capsule versus CT colonography in patients with incomplete colonoscopy: A pro-spective, comparative trial. Gut 2015, 64, 272-281. [CrossRef]

17. Teshima, C.W.; Kuipers, E.J.; Van Zanten, S.V.; Mensink, P.B.F. Double balloon enteroscopy and capsule endoscopy for obscure gastrointestinal bleeding: An updated meta-analysis. J. Gastroenterol. Hepatol. 2011, 26, 796-801. [CrossRef]

18. Kim, H.J.; Shim, C.S.; Lee, S.H.; Jung, I.S.; Hong, S.J.; Ryu, C.B.; Kim, J.O.; Cho, J.Y.; Lee, J.S.; Lee, M.S.; et al. The usefulness of capsule endoscopy in patients with obscure gastrointestinal bleeding. Korean J. Gastrointest. Endosc. 2005, 31, 140-146.

19. Jang, H.J.; Park, C.H.; Han, S.Y.; Byun, H.W.; Choi, M.H.; Kae, S.H.; Lee, J. Comparison of double balloon enteroscopy and capsule endoscopy for patients with suspected small bowel diseases. Korean J. Gastrointest. Endosc. 2007, 35, 379-384. [CrossRef]

20. Lee, B.J.; Chun, H.J.; Koo, J.S.; Keum, B.; Park, S.H.; Kim, D.R.; Kwon, Y.D.; Kim, Y.S.; Jean, Y.T.; Lee, H.S.; et al. Analysis of the factors that affect the diagnostic yield of capsule endoscopy in patients with obscure gastrointestinal bleeding. Korean J. Gastroenterol. 2007, 49, 79-84.

21. Ell, C.; Remke, S.; May, A.; Helou, L.; Henrich, R.; Mayer, G. The First Prospective Controlled Trial Comparing Wireless Capsule Endoscopy with Push Enteroscopy in Chronic Gastrointestinal Bleeding. Endoscopy 2002, 34, 685-689. [CrossRef]

22. Pennazio, M.; Santucci, R.; Rondonotti, E.; Abbiati, C.; Beccari, G.; Rossini, F.P.; De Franchis, R. Outcome of patients with obscure gastrointestinal bleeding after capsule en-doscopy: Report of 100 consecutive cases. Gastroenterology 2004, 126, 643-653. [CrossRef] [PubMed]

23. Lepileur, L.; Dray, X.; Antonietti, M.; Iwanicki-Caron, I.; Grigioni, S.; Chaput, U.; Di Fiore, A.; Alhameedi, R.; Marteau, P.; Ducrotté, P.; et al. Factors Associated With Diagnosis of Obscure Gastrointestinal Bleeding by Video Capsule Enteroscopy. Clin. Gastroenterol. Hepatol. 2012, 10, 1376-1380. [CrossRef] [PubMed]

24. Leung, W.K.; Ho, S.S.M.; Suen, B.-Y.; Lai, L.H.; Yu, S.; Ng, E.K.-W.; Ng, S.S.M.; Chiu, P.; Sung, J.J.Y.; Chan, F.K.; et al. Capsule Endoscopy or Angiography in Patients with Acute Overt Obscure Gastrointestinal Bleeding: A Prospective Randomized Study with Long-Term Follow-Up. Am. J. Gastroenterol. 2012, 107, 1370-1376. [CrossRef] [PubMed]

25. Segarajasingam, D.S.; Hanley, S.C.; Barkun, A.N.; Waschke, K.A.; Burtin, P.; Parent, J.; Mayrand, S.; Fallone, C.A.; Jobin, G.; Seidman, E.G.; et al. Randomized Controlled Trial Comparing Outcomes of Video Capsule Endoscopy with Push Enteroscopy in Obscure Gastrointestinal Bleeding. Can. J. Gastroenterol. Hepatol. 2015, 29, 85-90. [CrossRef]

26. Laine, L.; Sahota, A.; Shah, A. Does Capsule Endoscopy Improve Outcomes in Obscure Gastrointestinal Bleeding? Randomized Trial Versus Dedicated Small Bowel Radiography. Gastroenterology 2010, 138, 1673-1680. [CrossRef] [PubMed]

27. Han, J.W.; Hong, S.N.; Jang, H.J.; Jeon, S.R.; Cha, J.M.; Park, S.J.; Byeon, J.S.; Ko, B.M.; Kim, E.R.; Choi, H.; et al. Clinical Efficacy of Various Diagnostic Tests for Small Bowel Tumors and Clinical Features of Tumors Missed by Capsule Endoscopy. Gastroenterol. Res. Pract. 2015, 2015, 623208. [CrossRef]

28. Schulmann, K.; Hollerbach, S.; Kraus, K.; Willert, J.; Vogel, T.; Moslein, G.; Pox, C.; Reiser, M.; Reinacher-Schick, A.; Schmiegel, W. Feasibility and Diagnostic Utility of Video Capsule Endoscopy for the Detection of Small Bowel Polyps in Patients with Hereditary Polyposis Syndromes. Am. J. Gastroenterol. 2005, 100, 27-37. [CrossRef] [PubMed]

29. Iaquinto, G.; Fornasarig, M.; Quaia, M.; Giardullo, N.; D'Onofrio, V.; Iaquinto, S.; Di Bella, S.; Cannizzaro, R. Capsule endoscopy is useful and safe for small-bowel surveillance in familial ade-nomatous polyposis. Gastrointest. Endosc. 2008, 67, 61-67. [CrossRef]

30. Dionisio, P.M.; Gurudu, S.R.; Leighton, J.A.; Leontiadis, G.I.; Fleischer, D.E.; Hara, A.K.; Heigh, R.I.; Shiff, A.D.; Sharma, V.K. Capsule endoscopy has a significantly higher diagnostic yield in patients with suspected and established small-bowel Crohn's disease: A meta-analysis. Am. J. Gastroenterol. 2010, 105, 1240-1248, quiz 1249. [CrossRef] [PubMed]

31. Jensen, M.D.; Nathan, T.; Rafaelsen, S.R.; Kjeldsen, J. Diagnostic accuracy of capsule endoscopy for small bowel Crohn's disease is superior to that of MR enterography or CT enterography. Clin. Gastroenterol. Hepatol. 2011, 9, 124-129. [CrossRef]

32. Kharazmi, A.A.; Aslani, S.; Kristiansen, M.F.; Dahl, E.E.; Berner-Hansen, M. Indications and diagnostic yield of small-bowel capsule endoscopy in a real-world setting. BMC Gastroenterol. 2020, 20, 177. [CrossRef]

33. Mehdizadeh, S.; Chen, G.C.; Barkodar, L.; Enayati, P.J.; Pirouz, S.; Yadegari, M.; Ippoliti, A.; Vasiliauskas, E.A.; Lo, S.K.; Papadakis, K.A. Capsule endoscopy in patients with Crohn's disease: Diagnostic yield and safety. Gastrointest. Endosc. 2010, 71, 121-127. [CrossRef]

34. Luján-Sanchis, M.; Perez-Cuadrado-Robles, E.; García-Lledó, J.; Fernández, J.-F.J.; Elli, L.; Jimenez-Garcia, V.A.; Egea-Valenzuela, J.; Valle-Muñoz, J.; Carretero-Ribón, C.; Fernández-Urién-Sainz, I.; et al. Role of capsule endoscopy in suspected celiac disease: A European multi-centre study. World J. Gastroenterol. 2017, 23, 703-711. [CrossRef]

35. Keum, B.; Chun, H.J. Capsule endoscopy and double balloon enteroscopy for obscure gastrointestinal bleeding: Which is better? J. Gastroenterol. Hepatol. 2011, 26, 794-795. [CrossRef]

36. Pasha, S.F.; Hara, A.K.; Leighton, J.A. Diagnostic evaluation and management of obscure gastrointestinal bleeding: A changing paradigm. Gastroenterol. Hepatol. 2009, 5, 839-850. 
37. Singh, V.; Alexander, J.A. The evaluation and management of obscure and occult gastrointestinal bleeding. Abdom. Imaging 2009, 34, 311-319. [CrossRef] [PubMed]

38. Lin, S.; Rockey, D.C. Obscure gastrointestinal bleeding. Gastroenterol. Clin. N. Am. 2005, 34, 679-698. [CrossRef]

39. Zuckerman, G.R.; Prakash, C.; Askin, M.P.; Lewis, B.S. AGA technical review on the evaluation and management of occult and obscure gastrointestinal bleeding. Gastroenterology 2000, 118, 201-221. [CrossRef]

40. Wang, Z.; Chen, J.-Q.; Liu, J.-L.; Qin, X.-G.; Huang, Y. CT enterography in obscure gastrointestinal bleeding: A systematic review and meta-analysis. J. Med. Imaging Radiat. Oncol. 2013, 57, 263-273. [CrossRef] [PubMed]

41. Maglinte, D.D.T.; Kelvin, F.M.; O'Connor, K.; Lappas, J.C.; Chernish, S.M. Current status of small bowel radiography. Abdom. Imaging 1996, 21, 247-257. [CrossRef]

42. Gady, J.S.; Reynolds, H.; Blum, A. Selective arterial embolization for control of lower gastrointestinal bleeding: Recommendations for a clinical management pathway. Curr. Surg. 2003, 60, 344-347. [CrossRef]

43. Hartmann, D.; Schmidt, H.; Bolz, G.; Schilling, D.; Kinzel, F.; Eickhoff, A.; Huschner, W.; Moller, K.; Jakobs, R.; Reitzig, P.; et al. A prospective two-center study comparing wireless capsule endoscopy with in-traoperative enteroscopy in patients with obscure GI bleeding. Gastrointest. Endosc. 2005, 61, 826-832. [CrossRef]

44. Singh, A.; Marshall, C.; Chaudhuri, B.; Okoli, C.; Foley, A.; Person, S.D.; Bhattacharya, K.; Cave, D. Timing of video capsule endoscopy relative to overt obscure GI bleeding: Implications from a retrospective study. Gastrointest. Endosc. 2013, 77, 761-766. [CrossRef] [PubMed]

45. Shim, K.-N.; Moon, J.S.; Chang, N.K.; Hyuk, J.; Kim, J.H.; Min, B.H.; Jeon, S.R.; Kim, J.-O.; Choi, M.-G. Korean Gut Image Study Group Guideline for Capsule Endoscopy: Obscure Gastrointestinal Bleeding. Clin. Endosc. 2013, 46, 45-53. [CrossRef]

46. Carey, E.J.; Leighton, J.A.; Heigh, R.I.; Shiff, A.D.; Sharma, V.K.; Post, J.K.; Fleischer, D.E. A Single-Center Experience of 260 Consecutive Patients Undergoing Capsule Endoscopy for Obscure Gastrointestinal Bleeding. Am. J. Gastroenterol. 2007, 102, 89-95. [CrossRef]

47. Sidhu, R.; Sanders, D.S.; Kapur, K.; Leeds, J.S.; McAlindon, M.E. Factors predicting the diagnostic yield and intervention in obscure gastrointestinal bleeding investigated using capsule endoscopy. J. Gastrointest. Liver Dis. 2009, 18, $273-278$.

48. Shahidi, N.; Ou, G.; Svarta, S.; Law, J.K.; Kwok, R.; Tong, J.; Lam, E.C.; Enns, R. Factors Associated with Positive Findings From Capsule Endoscopy in Patients With Obscure Gastrointestinal Bleeding. Clin. Gastroenterol. Hepatol. 2012, 10, $1381-1385$. [CrossRef] [PubMed]

49. Triester, S.L.; Leighton, J.A.; Leontiadis, G.I.; Fleischer, D.E.; Hara, A.K.; Heigh, R.I.; Shiff, A.D.; Sharma, V.K. A Meta-Analysis of the Yield of Capsule Endoscopy Compared to Other Diagnostic Modalities in Patients with Obscure Gastrointestinal Bleeding. Am. J. Gastroenterol. 2005, 100, 2407-2418. [CrossRef]

50. Cobrin, G.M.; Pittman, R.H.; Lewis, B.S. Increased diagnostic yield of small bowel tumors with capsule endoscopy. Cancer 2006, 107, 22-27. [CrossRef]

51. Schwartz, G.D.; Barkin, J.S. Small-Bowel Tumors Detected by Wireless Capsule Endoscopy. Dig. Dis. Sci. 2007, 52, 1026-1030. [CrossRef]

52. Cheung, D.Y.; Kim, J.S.; Shim, K.-N.; Choi, M.-G. Korean Gut Image Study Group The Usefulness of Capsule Endoscopy for Small Bowel Tumors. Clin. Endosc. 2016, 49, 21-25. [CrossRef]

53. Huprich, J.E.; Fletcher, J.G.; Fidler, J.L.; Alexander, J.A.; Guimarães, L.S.; Siddiki, H.A.; McCollough, C.H. Prospective Blinded Comparison of Wireless Capsule Endoscopy and Multiphase CT Enterography in Obscure Gastrointestinal Bleeding. Radiology 2011, 260, 744-751. [CrossRef]

54. Van Weyenberg, S.J.; Bouman, K.; Jacobs, M.A.; Halloran, B.P.; Van der Peet, D.L.; Mulder, C.J.; Van Kuijk, C.; Van Waesberghe, J.H. Comparison of MR enteroclysis with video capsule endoscopy in the inves-tigation of small-intestinal disease. Abdom. Imaging 2013, 38, 42-51. [CrossRef] [PubMed]

55. Shyung, L.-R.; Lin, S.-C.; Shih, S.-C.; Chang, W.-H.; Chu, C.-H.; Wang, T.-E. Proposed Scoring System to Determine Small Bowel Mass Lesions Using Capsule Endoscopy. J. Formos. Med. Assoc. 2009, 108, 533-538. [CrossRef]

56. Girelli, C.M.; Porta, P.; Colombo, E.; Lesinigo, E.; Bernasconi, G. Development of a novel index to discriminate bulge from mass on small-bowel capsule endoscopy. Gastrointest. Endosc. 2011, 74, 1067-1074. [CrossRef] [PubMed]

57. Rondonotti, E.; Spada, C.; Adler, S.; May, A.; Despott, E.J.; Koulaouzidis, A.; Panter, S.; Domagk, D.; Fernandez-Urien, I.; Rahmi, G.; et al. Small-bowel capsule endoscopy and device-assisted enteroscopy for diagnosis and treatment of small-bowel disorders: European Society of Gastrointestinal Endoscopy (ESGE) Technical Review. Endoscopy 2018, 50, 423-446. [CrossRef]

58. Parsi, M.A.; Burke, C.A. Utility of capsule endoscopy in Peutz-Jeghers syndrome. Gastrointest. Endosc. Clin. N. Am. 2004, 14, 159-167. [CrossRef] [PubMed]

59. Ohmiya, N.; Taguchi, A.; Shirai, K.; Mabuchi, N.; Arakawa, D.; Kanazawa, H.; Ozeki, M.; Yamada, M.; Nakamura, M.; Itoh, A.; et al. Endoscopic resection of Peutz-Jeghers polyps throughout the small intestine at dou-ble-balloon enteroscopy without laparotomy. Gastrointest. Endosc. 2005, 61, 140-147. [CrossRef]

60. Burke, C.A.; Santisi, J.; Church, J.; Levinthal, G. The Utility of Capsule Endoscopy Small Bowel Surveillance in Patients with Polyposis. Am. J. Gastroenterol. 2005, 100, 1498-1502. [CrossRef]

61. Enns, R.A.; Hookey, L.; Armstrong, D.; Bernstein, C.N.; Heitman, S.J.; Teshima, C.; Leontiadis, G.I.; Tse, F.; Sadowski, D. Clinical Practice Guidelines for the Use of Video Capsule Endoscopy. Gastroenterology 2017, 152, 497-514. [CrossRef] 
62. Mata, A.; Llach, J.; Castells, A.; Rovira, J.M.; Pellise, M.; Ginès, A.; Fernández-Esparrach, G.; Andreu, M.; Bordas, J.M.; Piqué, J.M. A prospective trial comparing wireless capsule endoscopy and barium contrast series for small-bowel surveillance in hereditary GI polyposis syndromes. Gastrointest. Endosc. 2005, 61, 721-725. [CrossRef]

63. Gupta, A.; Postgate, A.J.; Burling, D.; Ilangovan, R.; Marshall, M.; Phillips, R.K.S.; Clark, S.K.; Fraser, C.H. A Prospective Study of MR Enterography Versus Capsule Endoscopy for the Surveillance of Adult Patients with Peutz-Jeghers Syndrome. Am. J. Roentgenol. 2010, 195, 108-116. [CrossRef] [PubMed]

64. Tescher, P.; Macrae, F.A.; Speer, T.; Stella, D.; Gibson, R.; Tye-Din, J.A.; Srivatsa, G.; Jones, I.T.; Marion, K. Surveillance of FAP: A prospective blinded comparison of capsule endoscopy and other GI imaging to detect small bowel polyps. Hered. Cancer Clin. Pract. 2010, 8, 3. [CrossRef]

65. Papadakis, K.A.; Tabibzadeh, S. Diagnosis and misdiagnosis of inflammatory bowel disease. Gastrointest. Endosc. Clin. N. Am. 2002, 12, 433-449. [CrossRef]

66. Mekhjian, H.S.; Switz, D.M.; Melnyk, C.S.; Rankin, G.B.; Brooks, R.K. Clinical features and natural history of Crohn's disease. Gastroenterology 1979, 77, 898-906. [CrossRef]

67. Cirillo, L.C.; Camera, L.; Della Noce, M.; Castiglione, F.; Mazzacca, G.; Salvatore, M. Accuracy of enteroclysis in Crohn's disease of the small bowel: A retrospective study. Eur. Radiol. 2000, 10, 1894-1898. [CrossRef] [PubMed]

68. Lescut, D.; Vanco, D.; Bonniere, P.; Lecomte-Houcke, M.; Quandalle, P.; Wurtz, A.; Colombel, J.F.; Delmotte, J.S.; Paris, J.C.; Cortot, A. Perioperative endoscopy of the whole small bowel in Crohn's disease. Gut 1993, 34, 647-649. [CrossRef] [PubMed]

69. an Hogezand, R.A.; Witte, A.M.; Veenendaal, R.A.; Wagtmans, M.J.; Lamers, C.B. Proximal Crohn's disease: Review of the clinicopathologic features and therapy. Inflamm. Bowel. Dis. 2001, 7, 328-337. [CrossRef] [PubMed]

70. Gay, G.J.; Delmotte, J.-S. Enteroscopy in Small Intestinal Inflammatory Diseases. Gastrointest. Endosc. Clin. N. Am. 1999, 9, 115-123. [CrossRef]

71. Goldberg, H.I.; Caruthers, S.B., Jr.; Nelson, J.A.; Singleton, J.W. Radiographic findings of the National Cooperative Crohn's Disease Study. Gastroenterology 1979, 77, 925-937. [CrossRef]

72. Eliakim, R.; Fischer, D.; Suissa, A.; Yassin, K.; Katz, D.; Guttman, N.; Migdal, M. Wireless capsule video endoscopy is a superior diagnostic tool in comparison to barium follow-through and computerized tomography in patients with suspected Crohn's disease. Eur. J. Gastroenterol. Hepatol. 2003, 15, 363-367. [CrossRef]

73. Girelli, C.M.; Porta, P.; Malacrida, V.; Barzaghi, F.; Rocca, F. Clinical outcome of patients examined by capsule endoscopy for suspected small bowel Crohn's disease. Dig. Liver Dis. 2007, 39, 148-154. [CrossRef]

74. Adler, S.; Hassan, C.; Metzger, Y.; Sompolinsky, Y.; Spada, C. Accuracy of automatic detection of small-bowel mucosa by second-generation colon capsule endoscopy. Gastrointest. Endosc. 2012, 76, 1170-1174. [CrossRef] [PubMed]

75. Gölder, S.K.; Schreyer, A.G.; Endlicher, E.; Feuerbach, S.; Schölmerich, J.; Kullmann, F.; Seitz, J.; Rogler, G.; Herfarth, H. Comparison of capsule endoscopy and magnetic resonance (MR) enteroclysis in suspected small bowel disease. Int. J. Color. Dis. 2005, 21, 97-104. [CrossRef] [PubMed]

76. Tillack, C.; Seiderer, J.; Brand, S.; Goke, B.; Reiser, M.F.; Schaefer, C.; Diepolder, H.; Ochsenkuhn, T.; Herrmann, K.A. Correlation of magnetic resonance enteroclysis (MRE) and wireless capsule endoscopy (CE) in the diagnosis of small bowel lesions in Crohn's disease. Inflamm. Bowel Dis. 2008, 14, 1219-1228. [CrossRef]

77. Solem, C.A.; Loftus, E.V., Jr.; Fletcher, J.G.; Baron, T.H.; Gostout, C.J.; Petersen, B.T.; Tremaine, W.J.; Egan, L.J.; Faubion, W.A.; Schroeder, K.W.; et al. Small-bowel imaging in Crohn's disease: A prospective, blinded, 4-way comparison trial. Gastrointest. Endosc. 2008, 68, 255-266. [CrossRef]

78. Hara, A.K.; Leighton, J.A.; Sharma, V.K.; Fleischer, D.E. Small Bowel: Preliminary Comparison of Capsule Endoscopy with Barium Study and CT. Radiology 2004, 230, 260-265. [CrossRef]

79. Gralnek, I.M.; Cohen, S.A.; Ephrath, H.; Napier, A.; Gobin, T.; Sherrod, O.; Lewis, J. Small Bowel Capsule Endoscopy Impacts Diagnosis and Management of Pediatric Inflammatory Bowel Disease: A Prospective Study. Dig. Dis. Sci. 2011, 57, 465-471. [CrossRef] [PubMed]

80. Pons Beltran, V.; Nos, P.; Bastida, G.; Beltran, B.; Arguello, L.; Aguas, M.; Rubin, A.; Pertejo, V.; Sala, T. Evaluation of postsurgical recurrence in Crohn's disease: A new indication for capsule endoscopy? Gastrointest. Endosc. 2007, 66, 533-540. [CrossRef] [PubMed]

81. Jonnalagadda, S.; Prakash, C. Intestinal strictures can impede wireless capsule enteroscopy. Gastrointest. Endosc. 2003, 57, 418-420. [CrossRef] [PubMed]

82. Ciorba, M.A.; Prakash, C. Wireless capsule endoscopy in the diagnosis of small bowel Crohn's disease. Inflamm. Bowel Dis. 2003, 9, 276. [CrossRef]

83. Barret, M.; Malamut, G.; Rahmi, G.; Samaha, E.; Edery, J.; Verkarre, V.; Macintyre, E.; Lenain, E.; Chatellier, G.; Cerf-Bensussan, N.; et al. Diagnostic Yield of Capsule Endoscopy in Refractory Celiac Disease. Am. J. Gastroenterol. 2012, 107, 1546-1553. [CrossRef] [PubMed]

84. Daum, S.; Wahnschaffe, U.; Glasenapp, R.; Borchert, M.; Ullrich, R.; Zeitz, M.; Faiss, S. Capsule endoscopy in refractory celiac disease. Endoscopy 2007, 39, 455-458. [CrossRef]

85. Eliakim, R.; Fireman, Z.; Gralnek, I.M.; Yassin, K.; Waterman, M.; Kopelman, Y.; Lachter, J.; Koslowsky, B.; Adler, S.N. Evaluation of the PillCam Colon capsule in the detection of colonic pathology: Results of the first multicenter, prospective, comparative study. Endoscopy 2006, 38, 963-970. [CrossRef] [PubMed] 
86. Van Gossum, A.; Munoz-Navas, M.; Fernandez-Urien, I.; Carretero, C.; Gay, G.; Delvaux, M.; Lapalus, M.G.; Ponchon, T.; Neuhaus, H.; Philipper, M.; et al. Capsule endoscopy versus colonoscopy for the detection of polyps and cancer. N. Engl. J. Med. 2009, 361, 264-270. [CrossRef] [PubMed]

87. Eliakim, R.; Yassin, K.; Niv, Y.; Metzger, Y.; Lachter, J.; Gal, E.; Sapoznikov, B.; Konikoff, F.; Leichtmann, G.; Fireman, Z.; et al. Prospective multicenter performance evaluation of the second-generation colon capsule compared with colonoscopy. Endoscopy 2009, 41, 1026-1031. [CrossRef]

88. Spada, C.; Hassan, C.; Munoz-Navas, M.; Neuhaus, H.; Deviere, J.; Fockens, P.; Coron, E.; Gay, G.; Toth, E.; Riccioni, M.E.; et al. Second-generation colon capsule endoscopy compared with colonoscopy. Gastrointest. Endosc. 2011, 74, 581-589. [CrossRef]

89. Spada, C.; Hassan, C.; Bellini, D.; Burling, D.; Cappello, G.; Carretero, C.; Dekker, E.; Eliakim, R.; de Haan, M.; Kaminski, M.F.; et al. Imaging alternatives to colonoscopy: CT colonography and colon capsule. European Society of Gastrointestinal Endoscopy (ESGE) and European Society of Gastrointestinal and Abdominal Radiology (ESGAR) Guideline-Update 2020. Eur. Radiol. 2021, 31, 2967-2982. [CrossRef]

90. Baltes, P.; Bota, M.; Albert, J.; Philipper, M.; Hörster, H.-G.; Hagenmüller, F.; Steinbrück, I.; Jakobs, R.; Bechtler, M.; Hartmann, D.; et al. PillCamColon2 after incomplete colonoscopy-A prospective multicenter study. World J. Gastroenterol. 2018, 24, 3556-3566. [CrossRef]

91. Pioche, M.; Ganne, C.; Gincul, R.; De Leusse, A.; Marsot, J.; Balique, J.; Fond, A.; Bretagnolle, M.; Henry, L.; Billaud, Y.; et al. Colon capsule versus computed tomography colonography for colorectal cancer screening in patients with positive fecal occult blood test who refuse colonoscopy: A randomized trial. Laryngo-Rhino-Otologie 2018, 50, 761-769. [CrossRef]

92. Thygesen, M.K.; Baatrup, G.; Petersen, C.; Qvist, N.; Krøijer, R.; Kobaek-Larsen, M. Screening individuals' experiences of colonoscopy and colon capsule endoscopy; a mixed methods study. Acta Oncol. 2019, 58, S71-S76. [CrossRef]

93. Negreanu, L.; Babiuc, R.; Bengus, A.; Sadagurschi, R. PillCam Colon 2 capsule in patients unable or unwilling to undergo colonoscopy. World J. Gastrointest. Endosc. 2013, 5, 559-567. [CrossRef]

94. Pioche, M.; de Leusse, A.; Filoche, B.; Dalbies, P.A.; Adenis Lamarre, P.; Jacob, P.; Gaudin, J.L.; Coulom, P.; Letard, J.C.; Borotto, E.; et al. Prospective multicenter evaluation of colon capsule examination indicated by colon-oscopy failure or anesthesia contraindication. Endoscopy 2012, 44, 911-916. [PubMed]

95. Alarcón-Fernández, O.; Ramos, L.; Adrián-De-Ganzo, Z.; Gimeno-Garcia, A.Z.; Nicolás-Pérez, D.; Jiménez-Sosa, A.; Quintero, E. Effects of Colon Capsule Endoscopy on Medical Decision Making in Patients with Incomplete Colonoscopies. Clin. Gastroenterol. Hepatol. 2013, 11, 534-540.e1. [CrossRef]

96. Neerincx, M.; Droste, J.T.S.; Mulder, C.; Räkers, M.; Bartelsman, J.; Loffeld, R.; Tuynman, H.; Brohet, R.; Van Der Hulst, R. Colonic work-up after incomplete colonoscopy: Significant new findings during follow-up. Endoscopy 2010, 42, 730-735. [CrossRef]

97. Katsinelos, P.; Chatzimavroudis, G.; Terzoudis, S.; Patsis, I.; Fasoulas, K.; Katsinelos, T.; Kokonis, G.; Zavos, C.; Vasileiadis, T.; Kountouras, J. Diagnostic Yield and Clinical Impact of Capsule Endoscopy in Obscure Gastrointestinal Bleeding during Routine Clinical Practice: A Single-Center Experience. Med. Princ. Pract. 2011, 20, 60-65. [CrossRef] [PubMed]

98. Hindryckx, P.; Botelberge, T.; De Vos, M.; De Looze, D. Clinical impact of capsule endoscopy on further strategy and long-term clinical outcome in patients with obscure bleeding. Gastrointest. Endosc. 2008, 68, 98-104. [CrossRef]

99. Cañas-Ventura, A.; Márquez, L.; Bessa, X.; Dedeu, J.M.; Puigvehí, M.; Delgado-Aros, S.; Ibáñez, I.A.; Seoane, A.; Barranco, L.; Bory, F.; et al. Outcome in obscure gastrointestinal bleeding after capsule endoscopy. World J. Gastrointest. Endosc. 2013, 5, 551-558. [CrossRef] [PubMed]

100. Ormeci, A.; Akyuz, F.; Baran, B.; Gokturk, S.; Ormeci, T.; Pinarbasi, B.; Soyer, O.M.; Evirgen, S.; Akyuz, U.; Karaca, C.; et al. What is the impact of capsule endoscopy in the long term period? World J. Gastrointest. Endosc. 2016, 8, 344-348. [CrossRef]

101. Moreno, C.; Arvanitakis, M.; Devière, J.; Van Gossum, A. Capsule endoscopy examination of patients with obscure gastrointestinal bleeding: Evaluation of clinical impact. Acta Gastro Enterologica Belg. 2005, 68, 10-14.

102. Timmer, A.; Breuer-Katschinski, B.; Goebell, H. Time trends in the incidence and disease location of Crohn's disease 1980-1995: A prospective analysis in an urban population in Germany. Inflamm. Bowel Dis. 1999, 5, 79-84. [CrossRef] [PubMed]

103. Pimentel, M.; Chang, M.; Chow, E.J.; Tabibzadeh, S.; Kirit-Kiriak, V.; Targan, S.R.; Lin, H.C. Identification of a prodromal period in Crohn's disease but not ulcerative colitis. Am. J. Gastroenterol. 2000, 95, 3458-3462. [CrossRef]

104. Urgesi, R.; Cianci, R.; Marmo, C.; Costamagna, G.; Riccioni, M.E. But how many misunderstood Crohn's disease are revealed "by chance" using Capsule Endoscopy in Chronic Recurrent OGIB? Experience of a Single Italian Center and long term follow-up. Eur. Rev. Med. Pharmacol. Sci. 2015, 19, 4553-4557. [PubMed]

105. Hansel, S.L.; McCurdy, J.D.; Barlow, J.M.; Fidler, J.; Fletcher, J.G.; Becker, B.; Prabhu, N.C.; Faubion, W.A.; Hanson, K.A.; Kane, S.V.; et al. Clinical Benefit of Capsule Endoscopy in Crohn's Disease: Impact on Patient Man-agement and Prevalence of Proximal Small Bowel Involvement. Inflamm. Bowel Dis. 2018, 24, 1582-1588. [CrossRef]

106. Lazarev, M.; Huang, C.; Bitton, A.; Cho, J.H.; Duerr, R.H.; McGovern, D.P.; Proctor, D.D.; Regueiro, M.; Rioux, J.D.; Schumm, P.P.; et al. Relationship between proximal Crohn's disease location and disease behavior and surgery: A cross-sectional study of the IBD Genetics Consortium. Am. J. Gastroenterol. 2013, 108, 106-112. [CrossRef]

107. Le Berre, C.; Trang-Poisson, C.; Bourreille, A. Small bowel capsule endoscopy and treat-to-target in Crohn's disease: A systematic review. World J. Gastroenterol. 2019, 25, 4534-4554. [CrossRef]

108. Cellier, C.; Green, P.H.; Collin, P.; Murray, J. ICCE Consensus for Celiac Disease. Endoscopy 2005, 37, 1055-1059. [CrossRef] 
109. Collin, P.; Rondonotti, E.; Lundin, K.E.; Spada, C.; Keuchel, M.; Kaukinen, K.; De Franchis, R.; Jacobs, M.A.; Villa, F.; Mulder, C.J. Video capsule endoscopy in celiac disease: Current clinical practice. J. Dig. Dis. 2011, 13, 94-99. [CrossRef] [PubMed]

110. Tennyson, C.A.; Green, P.H. The role of capsule endoscopy in patients with nonresponsive celiac disease. Gastrointest. Endosc. 2011, 74, 1323-1324. [CrossRef] [PubMed]

111. Gawron, A.J.; Veerappan, A.; Keswani, R.N. High success rate of repeat colonoscopy with standard endoscopes in patients referred for prior incomplete colonoscopy. BMC Gastroenterol. 2014, 14, 56. [CrossRef]

112. Kim, H.Y. Cecal intubation time in screening colonoscopy. Medicine 2021, 100, e25927. [CrossRef]

113. Cavallo, D.; Ballardini, G.; Ferrari, A.; Delconte, G.; Signoroni, S.; Sala, P.; Chiaravalli, S.; Massimino, M.; Bertario, L.; Vitellaro, M. Wireless capsule endoscopy in adolescents with familial adenomatous polyposis. Tumori J. 2015, 102, 40-44. [CrossRef] [PubMed]

114. Nam, S.-J.; Lim, Y.J.; Nam, J.H.; Lee, H.S.; Hwang, Y.; Park, J.; Chun, H.J. 3D reconstruction of small bowel lesions using stereo camera-based capsule endoscopy. Sci. Rep. 2020, 10, 6025-6028. [CrossRef]

115. Kwack, W.G.; Lim, Y.J. Current Status and Research into Overcoming Limitations of Capsule Endoscopy. Clin. Endosc. 2016, 49, 8-15. [CrossRef] [PubMed]

116. Shamsudhin, N.; Zverev, V.I.; Keller, H.; Pane, S.; Egolf, P.W.; Nelson, B.J.; Tishin, A.M. Magnetically guided capsule endoscopy. Med. Phys. 2017, 44, e91-e111. [CrossRef]

117. Yim, S.; Gultepe, E.; Gracias, D.H.; Sitti, M. Biopsy using a Magnetic Capsule Endoscope Carrying, Releasing, and Retrieving Untethered Microgrippers. IEEE Trans. Biomed. Eng. 2013, 61, 513-521. [CrossRef]

118. Tziortziotis, I.; Laskaratos, F.-M.; Coda, S. Role of Artificial Intelligence in Video Capsule Endoscopy. Diagnostics 2021, 11, 1192. [CrossRef]

119. Nam, J.; Oh, D.; Lee, S.; Song, H.; Lim, Y. Development and Verification of a Deep Learning Algorithm to Evaluate Small-Bowel Preparation Quality. Diagnostics 2021, 11, 1127. [CrossRef] [PubMed] 